\title{
19 \\ The work of rights: The nature of native title labour
}

\section{Pamela McGrath}

Australia's native title regime is, by any measure, a significant social phenomenon. In the two decades since the Native Title Act 1993 (Cwlth) (NTA) was passed into law, thousands of Aboriginal and Torres Strait Islander people and their advocates have actively pursued many hundreds of native title claims; at time of writing, 243 of these had been successful (National Native Title Tribunal 2014a). Collectively, these cover more than 2 million square kilometres ( 25 per cent) of the total Australian land mass (National Native Title Tribunal 2014b). And yet, despite the increasing numbers of Registered Native Title Bodies Corporate (RNTBCs) established to manage native title business on behalf of rights holders, there is a remarkable lack of research into how voluntary or obligatory participation in, or exclusion from, the regime impacts the lives of both Indigenous and non-Indigenous people. ${ }^{1}$

\footnotetext{
1 At the time of writing there were 132 RNTBCs (Australian Institute of Aboriginal and Torres Strait Islander Studies 2014). As outlined by McGrath et al. (2013: 27), 'When a group of Aboriginal or Torres Strait Islander people succeed in having their native title recognised in a Federal Court determination, they are required to nominate a body corporate to hold and manage (as trustee) or manage (as agent) their native title rights and interests. These corporations are known as Prescribed Bodies Corporate (PBCs) because they have prescribed characteristics under the NTA [Native Title Act 1993 (Cwlth)], including that they are incorporated under the Corporations (Aboriginal and Torres Strait Islander) Act 2006 (Cwlth) (the CATSI Act). Once registered by the National Native Title Tribunal (NNTT), as required by the NTA, they are technically known as Registered Native Title Bodies Corporate (RNTBCs)'.
} 
This paper reports on the preliminary findings of a case study that aims to address some of the deficiencies in existing accounts of the social impacts of native title, particularly in the area of labour and economic activity. The case study involved reviewing the native title activities of a Western Australian traditional owner group over a 15-year period, from around the time that their claim was first lodged in the late 1990s, to its determination 10 years later and including a five-year period of post-determination activities.

The various legal and policy assemblages of the native title regime together enable a complex and unique form of political economy that requires the labour of a wide range of specialist and nonspecialist participants. There is a growing body of research about the potential or otherwise of native title agreements to improve the economic circumstances of Indigenous Australians (see for example O'Faircheallaigh 2004, 2007; Langton \& Mazel 2012). But to date there has been very little attention paid to the labour implications of agreement making processes themselves, let alone any of the many other kinds of corporate activities associated with native title governance.

With the average resolution time for native title claims at one point reaching 13 years, the work of native title begins long before a determination is even made. ${ }^{2}$ But the work of native title doesn't stop once native title has been recognised. Along with the facilitation and management of future acts, the 'core' post-determination activities of RNTBCs include basic governance and compliance activities such as convening meetings of members and directors; maintaining accounts and corporate records; managing and distributing benefits to members; consulting members on major decisions; and annual reporting of finances and membership to the Office of the Registrar of Indigenous Corporations (ORIC) (Deloitte Access Economics 2014: 75). Depending on where RNTBCs are located, they might also undertake cultural heritage and land management activities; enterprise development;

2 The 2014 Social justice and native title report provides statistics from the Federal Court of Australia that indicate a significant reduction in the median time for resolution of applications determined in 2013-14 compared to previous years, from an average of 12 years and 11 months in June 2013 to an average of two years and six months as at 30 June 2014 (Gooda 2014: 77). 
service delivery; and political advocacy (Deloitte Access Economics 2014: 74). Some of these activities will be mandated by state or commonwealth legislation.

Significant to understanding the nature of the labour associated with RNTBCs is the fact that these corporations are not actually necessary to enabling the exercise of native title rights by the members of the native title group, who have already proven in court that they have their own body of laws and customs for governing rights in land. Rather, as conceptualised by Rowley (1972) and rearticulated by Levitus (2009), as Aboriginal organisations RNTBCs are a kind of carapace: 'simultaneously a transactional boundary and a point of articulation between external agencies and an Aboriginal domain' (Levitus 2009: 75). They are necessary to the effective operation of the native title system because they provide an interface for negotiation between Indigenous and non-Indigenous interests in land.

Recently there has been broad reporting of the fact that the vast majority of RNTBCs are poorly resourced to undertake the onerous work of managing and governing their native title (see Bauman et al. 2013, Deloitte Access Economics 2014). But there is little quantitative data available to illustrate the actual time and social effort such work involves. Nor are there any comprehensive ethnographic accounts of the character of native title labour and how it is being incorporated into contemporary Indigenous lifeworlds.

Working in collaboration with the Nyangumarta people of the east Pilbara through their RNTBC Nyangumarta Warrarn Aboriginal Corporation (NWAC), and the regional Native Title Representative Body (NTRB), Yamatji Marlpa Aboriginal Corporation (YMAC), this case study aims to address this gap. The preliminary findings reported here are based on data collected through an extensive review of legal and research files to capture information about the number and nature of native title related activities (e.g. meetings, surveys, field trips) and the number and identities of the individuals who participated in them over a 15-year period between 1999 and 2014. This has enabled an estimation of Nyangumarta people's investment of time on native title-related activities (measured in people days), and social effort (measured by number of external relationships). 
What emerges is a picture of a complex, dynamic and outwardly focused corporate domain that requires a lot of labour, much of it unpaid. This labour simultaneously reinforces place-based social identity while increasing social visibility and engagements with Australian society more broadly, bringing people together in old ways for new purposes that are rarely intramural.

I readily admit to being a newcomer to economic anthropology and I am indebted to Jon Altman's early work on hunter-gatherer economies for helping me think through the applicability of a time allocation methodology to understanding native title work. While acknowledging the difficulties with attempting to define labour and equating 'time' with 'work effort' (Altman 1987: 72), I proceed reassured by Jon's proposition that time spent is nevertheless an important measure of labour significance (1987: 71).

The Nyangumarta people's country is located in the east Pilbara between the town of Port Hedland and the community of Bidyadanga. It brings together desert and coast, and includes the majestic Eighty Mile Beach. Nyangumarta first started organising towards recognition of their native title in the mid-1990s, but it wasn't until 11 years later in 2009 that they achieved a consent determination over 33,000 square kilometres of country. In 2012 they achieved further recognition of jointly held rights with their Karajarri neighbours over an additional 2,000 square kilometres.

Nyangumarta people have described their native title journey as kaja karti marnti, 'our long walk'. ${ }^{3}$ In the words of senior woman Winne Coppin: 'It's been hard, going around talking, meeting, from the day one, start, till today [the day of their determination]' (YMAC 2010). Post-determination, the Nyangumarta group are responsible for the governance of two RNTBCs as well as a third Aboriginal corporation set up in 2003 in order to receive land previously held by the Aboriginal Lands Trust. They have initiated or been key partners in a number of community development and natural resource management projects including the Nyangumarta Ranger program, the Nyangumarta Warrarn Indigenous Protected Area, Eighty Mile Beach Marine Park, and the Kidson Track 4WD tourism route.

3 Kaja Karti Marnti is the title of a short film commissioned by YMAC in 2009 to document the long awaited Nyangumarta native title determination. 


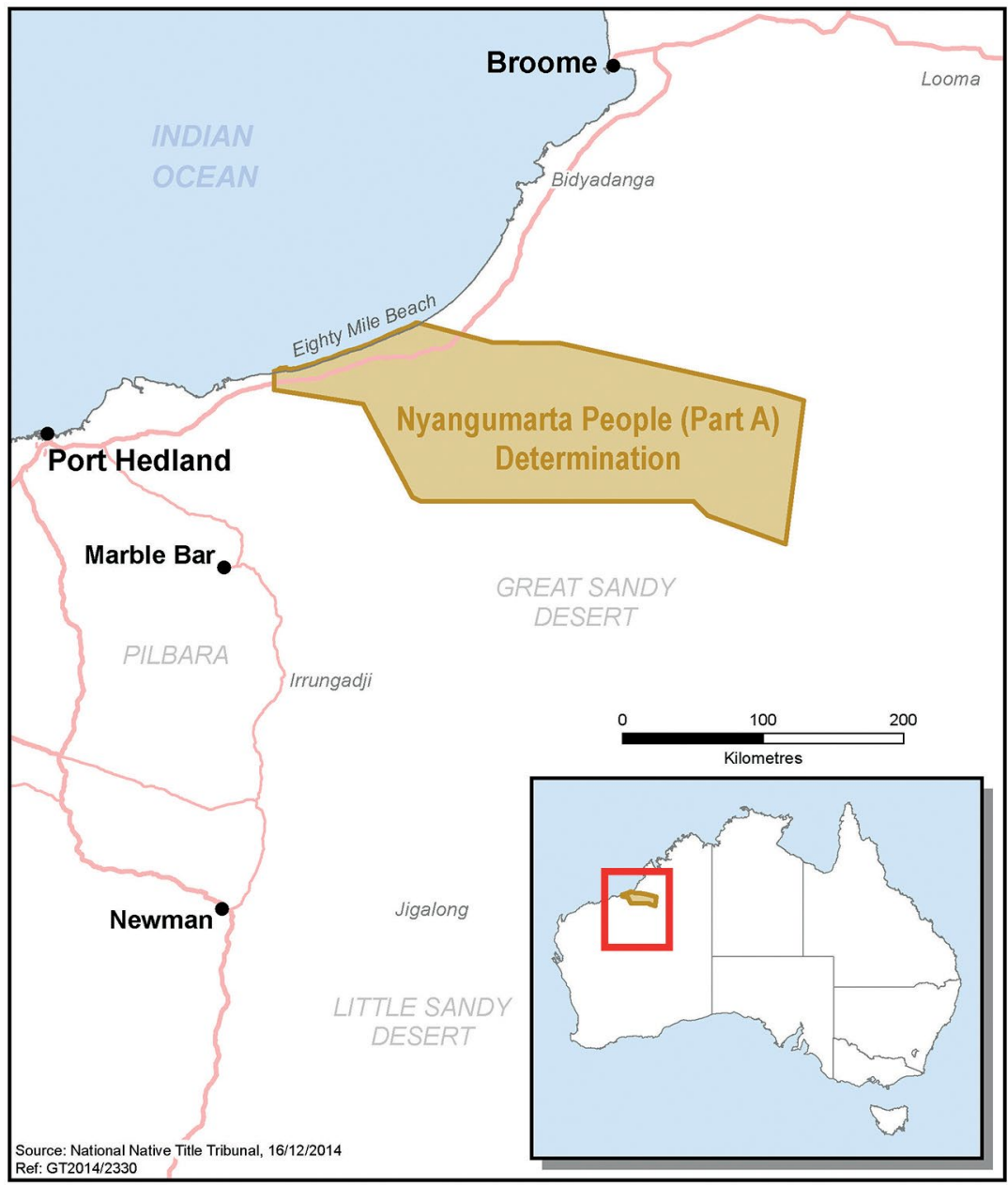

Fig. 19.1 Map of Nyangumarta native title determination area Source: National Native Title Tribunal

When reflecting on the figures that follow, it is worth bearing in mind that the work of native title doesn't get any less demanding than this. The dataset does not include undocumented or informal activities (such as phone calls and emails, travel and family meetings) and it is very likely that some records relating to formal activities have been lost or overlooked.

In addition, the particular circumstances of the Nyangumarta have resulted in workloads that are comparatively much less than other native title groups in the region. Indeed, when speaking to others who 
have worked in the Pilbara about the possibility of collaborating with Nyangumarta on this project, the universal response was along the lines of, 'But they don't do very much!'

The reasons for this comparatively low labour burden are complex. First, during the period under review the Nyangumarta had stable leadership and experienced minimal conflict within the group. Second, their connection evidence was strong and their claim was determined via meditation rather than litigation. Third, there were only a few non-government respondents to their claim (including three pastoralists, the fishing industry and Telstra), and for most of the time they were negotiating with a relatively supportive WA State government. Fourth, even during the heady days of the Pilbara mining boom there were few future acts notified and no operational mines on Nyangumarta land. And finally, the Nyangumarta have been fortunate to have a number of long-term relationships with NTRB support staff and advisors, including a senior anthropologist who has worked with them since 2000 .

All these factors reduce the amount of time people have to spend in meetings and on other activities in order to strategise, resolve disputes, educate outsiders and negotiate land access agreements, etc. Not all groups are so fortunate. On the other hand, NWAC has no independent source of income from mining agreements and relies entirely on small amounts of government funding, YMAC and volunteer labour to keep everything running.

Over the past 15 years, Nyangumarta people have spent a total of at least 2,728 days at almost 300 native title related events held over a total of 417 days (see Table 19.1). That is the equivalent of approximately seven and a half years of one person's time. Over 140 Nyangumarta people have been involved in these events, although the bulk of the work appears to have been undertaken by a core group of around 20 people, with the numbers of participants per event ranging from one to around 75 .

The majority of this effort- 58 per cent, or over 1,500 days' worth of Nyangumarta people's time - was spent in 146 meetings held over 175 days (see Table 19.1 and Fig. 19.2). Nyangumarta people spent a further 240 people days in 14 negotiation meetings in order to facilitate future acts. In addition to all these meetings, over these 15 years 
Nyangumarta people spent a total of 122 people days taking part in 23 heritage surveys. Most future act related activities (13 meetings and 15 surveys) took place after the Nyangumarta people's native title rights were first recognised in 2009. All activities related to mediation occurred prior to their native title determination.

For the Pilbara, 23 surveys over 15 years is a very light future act load. To put it in perspective, in the 2012-13 financial year alone YMAC facilitated 787 future act notices and organised 247 heritage surveys comprising 1,428 days on behalf of the 25 or so groups the organisation represents (YMAC 2013: 42, 94). That is an average of about 12 surveys per group for a single year. YMAC has described the current level of future act heritage work as placing 'considerable pressure on the native title groups we represent, particularly Elders with extensive cultural knowledge and authority who are required to participate in multiple surveys, often for weeks at a time' (YMAC 2014: 2).

Table 19.1 Nyangumarta native title work by activity type, 1999-2014

\begin{tabular}{|l|c|c|c|c|}
\hline Activity type & $\begin{array}{c}\text { Total no. } \\
\text { of events }\end{array}$ & $\begin{array}{c}\text { Total } \\
\text { days }\end{array}$ & $\begin{array}{c}\text { Nyangumarta } \\
\text { participation (days) }\end{array}$ & $\begin{array}{c}\% \text { of total time spent } \\
\text { on native title activities }\end{array}$ \\
\hline Meetings & 146 & 175 & 1576 & $58 \%$ \\
\hline Future act meetings & 13 & 15 & 240 & $9 \%$ \\
\hline Heritage surveys & 23 & 66 & 122 & $5 \%$ \\
\hline $\begin{array}{l}\text { Native title research } \\
\text { and legal testimony }\end{array}$ & 79 & 110 & 360 & $13 \%$ \\
\hline Mediations & 23 & 23 & 336 & $12 \%$ \\
\hline $\begin{array}{l}\text { Other field research } \\
\text { and workshops }\end{array}$ & 7 & 28 & 94 & $3 \%$ \\
\hline Total & 292 & 417 & 2728 & $100 \%$ \\
\hline
\end{tabular}

Source: Author's research 

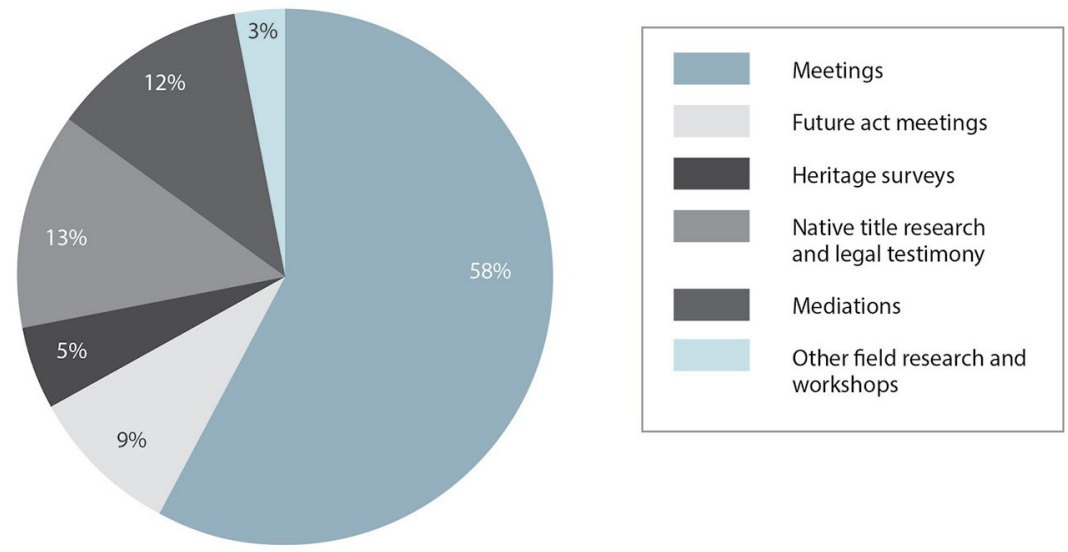

Fig. 19.2 Nyangumarta native title work by activity type (\% of total time of Nyangumarta participation)

Source: Author's research

Of all the native title related activities listed above, only future act meetings and heritage surveys (14 per cent of total time spent on native title activities) provide any significant compensation or formal payment for people's involvement. At the time of writing in late 2014, the average daily rate paid to an Aboriginal native title representative for participation as an advisor on a future act heritage survey was reported to be around $\$ 500$ per day (Norris O, pers. comm., 30 August 2014). Sitting fees for negotiation meetings vary between $\$ 300$ and $\$ 500$ per day. Although irregular and unpredictable, in a region where the unemployment rate for Indigenous Australians sits at around 14 per cent and the median weekly personal income at around \$297 (Australian Bureau of Statistics 2013), this is significant income for an individual. However, my research suggests that the total amount paid to members of the group for their participation in such activities over the 15-year period was less than $\$ 250,000$.

Turning to the social relations of native title work, the numbers and identities of the non-Nyangumarta people involved in Nyangumarta native title work during this period are significant: 345 nonNyangumarta people from 91 different organisations were involved in the 292 documented events. They included 116 bureaucrats; 61 mining executives; at least 45 lawyers representing NTRBs, respondent parties and government; 20 anthropologists; 10 archaeologists; eight business owners; five hydrologists; and four geologists. Fig. 19.3 sets 
out the numbers of people involved by profession (note that most of the anthropologists and lawyers involved worked for government or NTRBs and are not represented as separate professions). Around two thirds of these people were men; among the Nyangumarta themselves, there were more or less equal numbers of men and women involved. And in contrast to the situation of the Nyangumarta, it is very likely that most of these 345 non-Nyangumarta people were paid for their time, via either a salary or a daily consultancy rate.

The quality and intensity of the relationships between Nyangumarta people and these professional outsiders varied, but the findings indicate that the vast majority were brief and singular encounters between strangers. Only in a few instances have these relationships endured beyond one or two meetings.

The 91 organisations involved in the documented events (see Fig. 19.4) included NTRBs (3), mining companies (27), Commonwealth, State and local government departments (29), research organisations/consultants (8), pastoralist companies (3) and tourism ventures (2). The number of people involved who represented NTRBs is particularly striking: 104 staff from only three organisations. This reflects not only the number of professional staff needed to support a native title claim but also the difficulties many NTRBs face retaining qualified and experienced staff (for more discussion of NTRB capacity see Martin 2004, Deloitte Access Economics 2014).

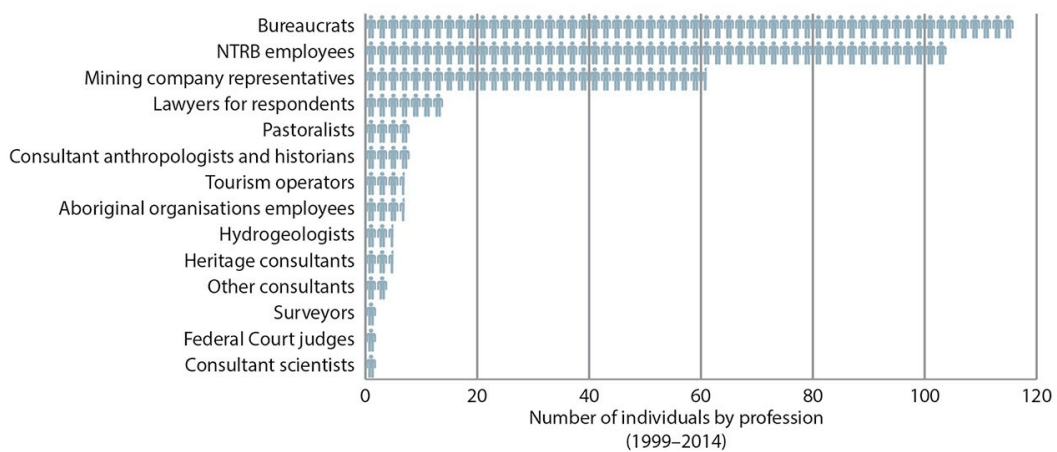

Fig. 19.3 Professions of non-Nyangumarta individuals involved in Nyangumarta native title activities, 1999-2014

Source: Author's research 


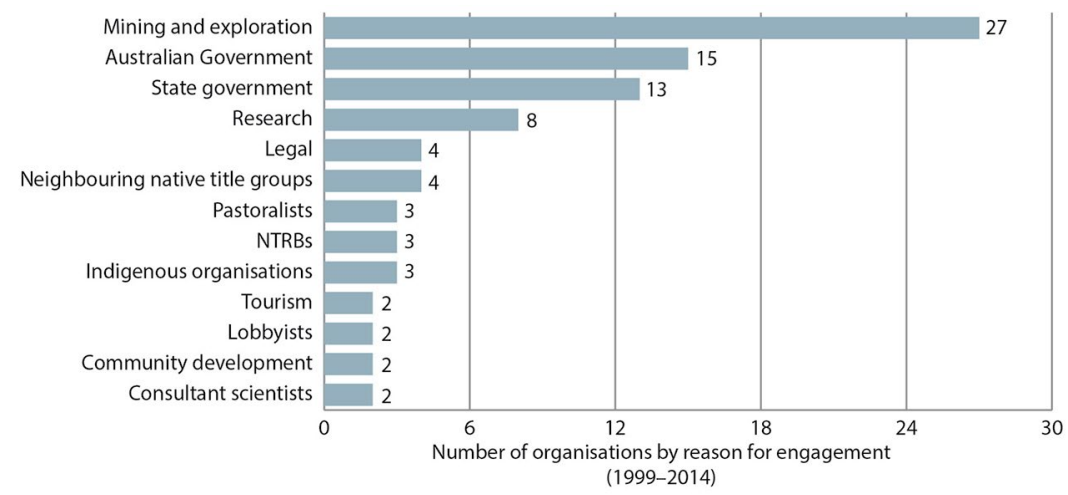

Fig. 19.4 Number of organisations involved in Nyangumarta native title activities by type, 1999-2014

Source: Author's research

Also notable are the numbers of people and agencies that Nyangumarta people have dealt with around land and sea management: at least 41 individuals from 11 agencies. This reflects the scale and complexity of the natural resource management projects that NWAC have been involved with, namely the Indigenous Protected Area and the Eighty Mile Beach Marine Park.

Finally, these figures point to the extent to which native title was born from and remains a project of government. Over 110 different representatives from just under 30 Commonwealth, State and local government departments have been in some way involved in the prosecution of the Nyangumarta native title claims and the postdetermination management of their rights. The role of government in this space has been truly diverse, with representatives coming to the table as respondents, mediators, facilitators, researchers, proponents of future acts, funders, policymakers, and potential project partners. While the introduction of the NTA in 1993 certainly doesn't mark the beginning of the bureaucratisation of Indigenous people's lives, native title doesn't appear to have at all lessened the burden of being governed.

Overall, these findings give a very concrete sense of the enormous commitment of time and social effort that Aboriginal and Torres Strait Islander peoples are prepared to make in order to secure formal legal recognition of traditional rights and interests in land. More analysis is required to understand the specific demands of post-determination 
governance, and it is hoped that further case studies will help illustrate the diversity of native title work for groups in different areas of the country.

There remains much to be learned about Nyangumarta people's perspectives on warkam (work). From interviews already conducted it is clear that native title work is very much seen as 'working for your people', and has been very empowering for Nyangumarta in many respects. But it comes at a cost, and those most heavily involved in the governance of NWAC at times find it challenging to balance this volunteer work with other family and professional commitments such as caring for elderly relatives or holding down a full-time job (Rose M, pers. comm., 3 June 2014).

Among other things, native title work has brought Nyangumarta people together in old ways for new purposes, leading to a strengthening of country group identity. It has rendered Nyangumarta people visible to outside interests and enabled them to insist on recognition of their traditional authority to an extent that was inconceivable only 20 years ago.

I am struck, however, by the frankness with which these figures illustrate the constant outwards orientation demanded by native title work; the unrelenting pulling of focus, resources and relationships away from Nyangumarta interests and aspirations towards those of others. This continuous outward orientation seems to me to be in clear tension with people's primary motivations for pursuing native title in the first place, and that is to achieve an easier and more frequent inward orientation, back towards country.

\section{References}

Altman JC (1987). Hunter-gatherers today: an Aboriginal economy in north Australia, Australian Institute of Aboriginal Studies, Canberra.

Australian Bureau of Statistics (2013). 2011 Census QuickStats: Aboriginal and Torres Strait Islander people - usual residents, www. censusdata.abs.gov.au/census_services/getproduct/census/2011/ quickstat/IARE506001?opendocument\&navpos $=220$. 
Australian Institute of Aboriginal and Torres Strait Islander Studies (2014). Registered Native Title Bodies Corporate summary, www. aiatsis.gov.au/_files/ntru/rntbc/registered_native_title_bodies_ corporate_summary_2014.pdf.

Bauman T, Strelein LM \& Weir JK (2013). Navigating complexity: living with native title. In Bauman T, Strelein LM \& Weir JK (eds), Living with native title: the experiences of registered native title corporations, Australian Institute of Aboriginal and Torres Strait Islander Studies, Canberra.

Deloitte Access Economics (2014), Review of the roles and functions of native title organisations, Deloitte Access Economics Pty Ltd, Kingston ACT.

Gooda M (2014). Social Justice and Native Title Report 2014, Aboriginal and Torres Strait Islander Social Justice Commissioner, Australian Human Rights Commission, Sydney.

Langton M \& Mazel O (2012). The resource curse compared: Australian Aboriginal participation in the resource extraction industry and distribution of impacts. In Langton M \& Longbottom J (eds), Community futures, legal architecture: foundations for Indigenous peoples in the global mining boom, Routledge, Oxon UK.

Levitus R (2009). Aboriginal organisations and development: the structural context. In Altman JC \& Martin DF (eds), Power, culture, economy: Indigenous Australians and mining, CAEPR Research Monograph No. 30, ANU E Press, Canberra.

Martin D (2004). Capacity of anthropologists in native title practice, report to the National Native Title Tribunal, Anthropos Consulting Services, Canberra.

McGrath PF, Stacey C \& Wiseman L (2013). An overview of the Registered Native Title Bodies Corporate regime. In Bauman $\mathrm{T}$, Strelein LM \& Weir JK (eds), Living with native title: the experiences of registered native title corporations, Australian Institute of Aboriginal and Torres Strait Islander Studies, Canberra.

National Native Title Tribunal (2014a). Statistics: native title determinations, www.nntt.gov.au/Pages/Statistics.aspx. 
National Native Title Tribunal (2014b). Determinations of native title (as at 30 September 2014), www.nntt.gov.au/Maps/Determinations_ map.pdf.

O'Faircheallaigh C (2004). Evaluating agreements between Indigenous people and resource developers. In Langton M, Tehan M, Palmer L \& Shain K (eds), Honour among nations? Treaties and agreements with Indigenous peoples, Melbourne University Press, Carlton.

O'Faircheallaigh C (2007). 'Unreasonable and extraordinary restraints': native title, markets and Australia's resources boom. Australian Indigenous Law Review 11(3):28-42.

Rowley C (1972). Outcasts in White Australia, Penguin Books, Harmondsworth.

YMAC (Yamatji Marlpa Aboriginal Corporation) (2010). Kaja karti marnti [The long walk], video recording, vimeo.com/98205705.

YMAC (Yamatji Marlpa Aboriginal Corporation) (2013). Annual Report 2013, YMAC, Perth.

YMAC (Yamatji Marlpa Aboriginal Corporation) (2014). Submission no. 034 to the Inquiry into non-financial barriers to mineral and energy resource exploration, Productivity Commission, Canberra. 
This text is taken from Engaging Indigenous Economy: Debating diverse approaches, edited by Will Sanders, published 2016 by ANU Press, The Australian National University, Canberra, Australia. 